\title{
The Role of Cultural Competence in the Teaching of Hungarian as a Foreign Language and in Cultural Diplomacy ${ }^{1}$
}

\author{
Erika Sólyom
}

\begin{abstract}
In the present paper, I aim to shed light on the importance of cultural competence from three perspectives. First, in my capacity as a sociolinguist, I will talk about how Hungarian culture is incorporated in the textbook Colloquial Hungarian (Rounds and Sólyom 2011), providing particular examples from various dialogues and cultural notes from the book. I believe that linguistic competence, communicative competence, and cultural competence are equally important parts of foreign language teaching and foreign language learning. Second, as a foreign language instructor at U.S. study abroad programs, I plan to discuss the importance of cultural norms of the speakers of the local language in the host country. Third, as a director of an American cultural and resource center in Budapest, I will talk about the importance of building bridges between two cultures, describing the goals and missions of the center as well as giving specific examples of the activities of the American Corner Budapest.
\end{abstract}

Keywords: Cultural Competence, Communicative Competence, Foreign Language Teaching, Hungarian as a Foreign Language, American Corners, Cultural diplomacy

Biography: Erika Sólyom earned her B.A. degree in Russian and English Studies (EKTF, Eger) and received her first M.A. in English Language and Literature (ELTE, Budapest) in Hungary. In 2003 and 2005, respectively, she earned an M.A. and an M.Phil. in Linguistics at New York University. Her research interests are in intercultural communication, minority language education, linguistic human rights, language and gender, as well as language change and globalization. Since 2004, she has been teaching Hungarian as a Foreign Language for U.S. study abroad students of ELTE and Corvinus University of Budapest, where she is also the director of the American Corner Budapest, a cultural and resource center. In 2002, she published with Carol H. Rounds Colloquial Hungarian in Routledge's Language Learning Series, a new edition of which came out in 2011. In 2003, she was awarded a U.S. Fulbright-Hays fellowship and conducted research on Hungarian language change since the collapse of communism in 1989. Her sociolinguistic findings appeared in Comparative Hungarian Cultural Studies, edited by Steven Tötösy de Zepetnek and Louise O. Vasvári in 2011.

${ }^{1}$ Parts of this paper have been presented at the IJAS conference in Rome (October, 2013) and delivered as one of the keynote speeches at the Fifth Anniversary Celebration of PREZI in Budapest (April, 2014). In addition, in 2011, a segment about the 'can-do' culture and the American Corner Budapest also appeared in the GE for CEE Blog (http://geforcee.geblogs.com/can-do-culture/). 
Sólyom, Erika. "The Role of Cultural Competence in the Teaching of Hungarian as a Foreign Language and in Cultural Diplomacy." Hungarian Cultural Studies. e-Journal of the American Hungarian Educators Association, Volume 7 (2014): http://ahea.pitt.edu DOI: 10.5195/ahea.2014.147

In the present paper, I synthesize my teaching and other professional experiences from the three types of work activities, all concerning English and Hungarian relationships, that I have been involved with during the past two decades. By profession, I am the director of an American cultural and resource center, the American Corner Budapest. By passion, I am a cultural anthropologist with special interest in West Africa, in particular Senegal. By academic training, I am foreign language teacher and a sociolinguist. For years I taught Russian as a Foreign Language and English as a Foreign Language for Hungarians and in the past ten years or so, I have been teaching Hungarian as a Foreign Language for study abroad students, as well as for professionals. The overarching themes in both my personal, professional and academic lives are language and culture.

Cultural competence, which refers to an ability to interact effectively with people of different cultures, has been widely analyzed in the professional world (e.g., in the works of governments, mediators, non-governmental organizations, human resource offices, etc.), and has also attracted considerable academic interest in the field of linguistics and education. Within education, the discussion has concentrated on the training and the education of teachers and school staff and the developing of their cultural competence, especially with the growing diversity of students in classrooms worldwide. Being a culturally competent educator means valuing diversity and respecting differences of students. Cultural competence goes hand in hand with communicative competence, a term that was coined in the sixties by the sociolinguist, Dell Hymes (Hymes 1966, 1972). According to communicative competence, in order to reach successful communication, language users should not only correctly use language but also use it appropriately, incorporating many components of the actual context.

In the present paper, I aim to shed light on the importance of cultural competence from three perspectives. First, in my capacity of a sociolinguist, I will talk about how Hungarian culture is incorporated in the language textbook Colloquial Hungarian (Rounds and Sólyom 2011), providing particular examples from various dialogues and cultural notes of the book. With the specific examples, as Karen Ogulnick (2005: 250-54) explains, I will underline the fact that, "beyond knowing words and grammar, learning a language involves acquiring a role, and knowing how to act according to that social definition." Second, as a foreign language instructor at study abroad programs, for example at UC California-ELTE Budapest and at the International Study Programs at Corvinus University of Budapest, I plan to discuss the importance of cultural norms and customs of the speakers of the local language in the host country. Third, as a director of an American cultural and resource center in Budapest, I will talk about the importance of building bridges between two cultures, describing the goals and missions of the center as well as giving specific examples of the activities of the American Corner Budapest.

On the one hand, as a sociolinguist and educator, I find it important to expand the question of "Who is a culturally competent educator?" to the following inquiry: "Who is a culturally competent second/foreign language teacher?” As Claire Kramsch (1995: 89) puts it:

Despite the advances made by research in the spheres of the intercultural and the multicultural, language teaching is still operating on a relatively narrow conception of both language and culture. Language continues to be taught as a fixed system of formal structures and universal speech functions, a neutral conduit for the transmission of cultural knowledge. 
Sólyom, Erika. "The Role of Cultural Competence in the Teaching of Hungarian as a Foreign Language and in Cultural Diplomacy." Hungarian Cultural Studies. e-Journal of the American Hungarian Educators Association, Volume 7 (2014): http://ahea.pitt.edu DOI: 10.5195/ahea.2014.147

In her study, Kramsch concludes that in the future the language teacher has to be defined "not only as the impresario of a certain linguistic performance but as the catalyst for an ever-widening critical cultural competence." On the other hand, as a foreign language instructor at U.S. study abroad programs in Hungary as well as a director of an U.S. cultural center, I also find it important to underline the importance of cultural competence during the orientation week and introductory phase of study abroad programs, as well as during the programming of foreign cultural centers.

Coming from a linguistics background, I would like to start off with a brief introduction to linguistics and draw the reader's attention to a famous Swiss linguist of the late nineteenth century, Ferdinand de Saussure (1857-1913), who showed that the language faculty is composed of two aspects: langue (the language system) versus parole (the act of speaking, i.e. language use/speech). The importance of this juxtaposition is reflected when we talk about the theoretical/abstract knowledge of language (see further Chomsky 1965) as opposed to performance, i.e. the appropriate social use of language (see further Hymes 1966). The former is related to a speaker's linguistic/grammatical competence, the latter is related to communicative competence. In actuality, parole is the concrete use of language in social and cultural context. For sociolinguists and linguistic anthropologists, this particular social and cultural context is of crucial importance, and given its importance it should be a concern also for foreign language teachers. As Kramsch (1995: 85) explains:

Material culture is constantly mediated, interpreted and recorded-among other things - through language. It is because of that mediatory role of language that culture becomes the concern of the language teacher.

In agreement with many scholars and educators, I share the belief that foreign language teachers should develop not only linguistic and communicative competence but that they should also aim at teaching culture and help develop cultural competence in a foreign language classroom as communication breakdowns typically arise not from the linguistic but from the socio-linguistic differences (Krasner 1999: 81). For example, a student learning a foreign language may produce well-formed, grammatical sentences but without the proper cultural frame of the target language, s/he may face difficulties or fail communicational goals. In the academic literature, the sociolinguistic and sociocultural aspects are many times addressed under the heading of pragmatics, defined as the study of communicative action in its sociocultural context (on which see Rose and Kasper 2001).

Based on my twenty years of foreign language teaching experience both in the United States and in Hungary, I also believe that teaching culture in a foreign language class is essential from the first moment of the class, in order to raise awareness of the language learners' own cultural worldview, to pinpoint cultural differences between the culture of the target language and that of the language learners. In addition, it is also important to teach about different cultural practices and cultural frames as well as to develop cross-cultural skills (Krasner 1999: 83).

For the past ten years or so, I have been involved with teaching Hungarian as a Foreign Language for international study abroad students as well as foreign professionals in Budapest. During my classes, as basic course material throughout the semester, I use the book I coauthored with Carol. H. Rounds, Colloquial Hungarian (2011). On the first day of class, I immediately introduce three other books about Hungarian culture: Zsuzsanna Ardó's How to be 
Sólyom, Erika. "The Role of Cultural Competence in the Teaching of Hungarian as a Foreign Language and in Cultural Diplomacy." Hungarian Cultural Studies. e-Journal of the American Hungarian Educators Association, Volume 7 (2014): http://ahea.pitt.edu DOI: 10.5195/ahea.2014.147

a European? Go Hungarian! (1994) and Culture Shock! (2008). These two publications are complemented by a third book, Todd Williams's You! Hungarians from an African American Perspective (2004). During each class of the semester, in addition to the grammar from our textbook I introduce a chapter from one of these books. In his book, Williams (2004) discusses issues related to general cultural information about Hungary, customs, traditions, entertainment, people, everyday interactions and urban folklore, all with a great sense of humor from the perspective of an outsider. The same sense of humor is present throughout the pages of Ardo's books $(1994,2008)$, this time, however, from the perspective of an insider. According to the lines on the front cover of Ardó's Culture Shock!, the book is a survival guide to customs and etiquette of Hungarians. Similarly, the back cover promises "generous doses of humor" and that "this book is filled with insights and useful information indispensable to understanding this unique land," i.e. Hungary. In addition to the above publications on Hungarian culture, it should be noted that our Colloquial Hungarian course book chapters also finish with a heading called Cultural Notes, addressing a specific topic of Hungarian culture. With my students, I discuss and review these cultural notes as well as incorporate them into the language activities during the Hungarian classes.

As an introduction to the language textbook and the books on Hungarian culture, I also introduce the semester with a cultural chart, which we revisit on each occasion the class meets. The chart includes specific areas of interest within the framework of intercultural communication. For example, it is inevitable to start the first day of the semester with the question Hogy vagy? ['How are you?']. It is not surprising that my American students react with a "Fine!" or a "Great!" response and within a day they switch into Hungarian and say Fantasztikusan! ['Fantastic!']. And then, as a not so well-behaving language teacher, I scream: 'No, no, no! You cannot answer Fantasztikusan! ['Fantastic!'] to a 'How-are-you?' question when you speak Hungarian." My students are surprised when they learn that for a Hungarian, the response to the "How are you?" question is hardly ever "Great!" but "OK!" at best and after (or, instead of that quick "OK!") a long list of complaints will follow: the weather is bad, my head is hurting, I had a rough night and the neighbor was quite nasty this morning and my kidney stones are acting up, and the list goes on and on.

Apart from the explicit information provided in the previous paragraph, cultural information can be hidden or, in other words, integrated implicitly in many foreign language activities. The dialogues of the language course books can be enriched by cultural, linguistic, and extra-linguistic information. Our Colloquial Hungarian course book was first published by Routledge in 2003 (Rounds and Sólyom 2003) but in the new, revised, expanded third edition that came out in 2011 we realized it was important to incorporate additional exchanges with cultural references from the very first page. When we updated the dialogues, we paid special attention to incorporating much more implicit cultural information into the dialogues and texts. One of the first dialogues we rewrote was in the opening chapter (Rounds and Sólyom 2011: 45):

$\begin{array}{ll}\text { MIKE } & \text { What is this? } \\ \text { ZSUZSI } & \text { This is the snack bar. } \\ \text { MIKE } & \text { What is that? } \\ \text { ZSUZSI } & \text { That is a Túró Rudi vending machine. } \\ \text { MIKE } & \text { Interesting. And what is this? } \\ \text { ZSUZSI } & \text { This is a classroom. That, on the other hand, is an office. }\end{array}$


Sólyom, Erika. "The Role of Cultural Competence in the Teaching of Hungarian as a Foreign Language and in Cultural Diplomacy." Hungarian Cultural Studies. e-Journal of the American Hungarian Educators Association, Volume 7 (2014): http://ahea.pitt.edu DOI: 10.5195/ahea.2014.147

$\begin{array}{ll}\text { MIKE } & \text { Mi ez? } \\ \text { ZSUZSI } & \text { Ez a büfé. } \\ \text { MIKE } & \text { Mi az? } \\ \text { ZSUZSI } & \text { Az egy Túró Rudi automata. } \\ \text { MIKE } & \text { Érdekes. És mi ez? } \\ \text { ZSUZSI } & \text { Ez egy tanterem. Az pedig egy iroda. }\end{array}$

The foregoing example illustrates that a simple question in Unit One like "What's this?" or "What's that?" which in the earlier edition of our text had a response with no cultural reference in our previous book like "This is a book" and "That is a notebook." In the new edition, however, the sentence has been changed into "This is a cottage cheese candy bar vending machine." A language learner with raised eyebrows may immediately ask: "A WHAT?? A cottage-cheese-candy bar vending machine??" And that is exactly where culture steps in with a so-called Wow-factor. And this Wow-factor or Wow-experience is one of the most important methods and goals during my foreign language teaching. The Túró Rudi ['farmer cheese candy bar'] is an old-time favorite candy bar of Hungarians. One piece of this candy bar is one dividing zone between a Hungarian and a non-Hungarian. So watch out in Budapest when you are asked the seemingly innocent question: "Do you like Túró Rudi?"

The integration of cultural information into the textbook is true for other revised sections of the Cultural Notes in the new Colloquial Hungarian. For example, in Unit Fourteen, we introduced the famous and infamous Hungarian outdoor activity of the very unhealthy szalonnasütés ['bacon barbecue'] or the kávéházi kultúra ['coffee house culture'] with the unforgettable world of Hungarian pastries. Our explicit Cultural Notes sections and dialogues not only go hand in hand with cultural information, but with teaching grammar (for example, in the section introducing grammatical cases), we also attempted to add cultural notes. In the new edition of our textbook, the locational suffixes appear in dialogues that introduced well-known, new spots in the city, such as the so-called romkocsmák ['ruin pubs']. Ruin pubs are trendy, improvised, cheap, usually outdoor pubs, often located in abandoned buildings in Budapest. Thus, in the revised edition of our course book, in Unit Seven, instead of boring or old-fashioned scenes and locations in the dialogues, such as at the post-office or the train station or the bank, we found creative ways to incorporate a fun location for the Hungarian locational suffixes (Rounds and Sólyom 2011: 129):

MIKE Where are you going tonight?

FERI To a ruin pub in Pest. Are you familiar with ruin pubs?

MIKE Of course! Everyone knows about the famous ruin pubs in Pest. I'll come, too, that's not a problem is it?

FERI Of course not! Will you bring a map, too?

MIKE I know it is a little strange to everybody, but I take a map everywhere.

MIKE Hova mész ma este?

FERI Egy pesti romkocsmába. Ismered a romkocsmákat?

MIKE Persze! Mindenki ismeri Pesten a híres romkocsmákat! Jövök én is, nem baj?

FERI Dehogy! Hozol térképet is?

MIKE Tudom, ez egy kicsit furcsa mindenkinek, de mindenhova viszek térképet. 
Sólyom, Erika. "The Role of Cultural Competence in the Teaching of Hungarian as a Foreign Language and in Cultural Diplomacy." Hungarian Cultural Studies. e-Journal of the American Hungarian Educators Association, Volume 7 (2014): http://ahea.pitt.edu DOI: 10.5195/ahea.2014.147

According to Krasner (1999: 87) in a foreign language classroom, both linguistic and extra-linguistic cultural features should be taught. Otherwise, the end result may be miscommunication, misinterpretation, or even a major culture shock on the part of the students aiming to learn a particular language. Raising students' awareness about the new culture is like building bridges. I believe that we-as educators, teachers, and especially foreign language teachers - should all act like cultural bridges, and builders of these cultural bridges. The topic of cultural bridge building in my foreign language classroom takes me to a different location of bridge building, to an American cultural and resource center, where I have been working as a director since 2009. The American Corners Initiative is a U.S. State Department program with about six hundred Corners worldwide. The goal of the American Corners Initiative is to promote cultural diplomacy and the respect and recognition of cultural diversity and heritage.

The American Corner Budapest was founded in 2009 as a partnership between the U.S. Embassy and Corvinus University of Budapest. The American Corners act as information and resource centers as well as small cultural or public diplomacy centers around the world. Political scientist Milton C. Cummings (2003) refers to cultural diplomacy as the field for exchanging ideas, information, values, systems, traditions, beliefs and other aspects of culture in order to foster and reach mutual understanding between peoples and nations. Such exchanges can be reached through arts, culture, tradition or education, just to name a few.

Programs about American arts, culture, tradition, or education are all in the focal point of the American Corner Budapest. The center organizes fifty-plus cultural programs annually. The thematically arranged programs are all based on U.S. calendar events but there are also international celebrations. All the Corner programs are free and all visitors are welcome. The programs include Event Series, Special Events and Regular Programs. Event Series are programs that consist of many parts, run throughout the year and have a unifying theme. Special Events are single events such as lectures, workshops, round-tables, performances, exhibitions, high school outreach programs, concerts or film screenings. Regular Programs are bi-weekly or monthly events such as Bicultural Bridges with special themes that connect American and Hungarian cultures, TALC (Tuesday American Language Club), the recently launched Kindle Club and MUSE Music Club with special focus on folk music. Folk music, in particular can be used as an effective teaching tool to unite us not only across cultures, but it also tells us something about our own culture: how people think, interact and live in the village or the city, in the new world or the old.

Many programs at the American Corner Budapest share an underlying theme: the American "can-do" attitude, which has existed since the beginning of the nation. In the U.S., the ideals of independence fostered the growth of one main concept, the American Dream. From birth, Americans learn values associated with this Dream. A popular children's book, The Little Engine That Could, tells the story of an engine that has to fight its way to the top of a large hill. The engine repeats to itself, "I think I can, I think I can." The engine accomplishes its goal and the lesson children learn is that with enough perseverance and determination, they can reach their goals. Many years after the words of the little engine, a very similar three-word message of "Yes, we can" appeared in the Obama campaign, and these three simple words, according to Molly McGuire (2010), inspired a generation and united a community.

The "can-do" message is present in the American Corner Budapest's TALC Language Club that encourages visitors to have confidence in themselves and their skills so that they can take the initiative to practice their English. During our Tolerance Series on the Civil Rights 
Sólyom, Erika. "The Role of Cultural Competence in the Teaching of Hungarian as a Foreign Language and in Cultural Diplomacy." Hungarian Cultural Studies. e-Journal of the American Hungarian Educators Association, Volume 7 (2014): http://ahea.pitt.edu DOI: 10.5195/ahea.2014.147

Movement, international human rights activists, educators, and writers emphasized the importance of activism and the "can-do" attitude that has guided many African Americans throughout the years to fight for freedom. The word "can" (or rather, "Yes, we can!") quoted above has been voiced repeatedly throughout the Obama campaign during the presidential election. Wolfgang Mieder (2009), who dedicated a book to the Obama rhetoric and oratory, analyzes the effective use of proverbs and proverbial phrases as the president outlined his promise for change during the presidential campaign. As the author notes (Mieder 2009: viii), "no matter what Barack Obama writes or speaks about, his prose or speech contains metaphorical language that makes his rhetoric and oratory universally accessible," and for the 2008 campaign "Yes, we can!" was the central trope of his oratory.

The "can-do" attitude and "can-do" spirit is a positive vision that is present not only in the political arena, but also in the business world. The topic of business and entrepreneurship has also played a large part in American Corner Budapest's curriculum. For example, in partnership with the U.S. Embassy in Budapest, the Budapest Corner organized a Strategic Business Plan Workshop for Entrepreneurs where dynamic speakers delivered engaging presentations throughout the semester. In sum, what the little engine could and did, what many Americans tried and achieved, what African Americans dreamt, fought for and came to realize, the American Corner Budapest also tries to accomplish with its programs and with its mission.

Teaching language and teaching culture is a very complex matter. I believe that we, in our roles as sociolinguists, teachers, educators, study abroad program organizers, and public diplomacy advocates, are all cultural ambassadors and builders of invaluable bridges. At an IJAS conference that took place in Rome in the fall of 2013, the following sticker was in our conference package: "I love Rome. Like my research, Rome was not built in one day." Similarly, the above-mentioned cultural bridges are not made within one day either. The work we do may take a long while but it is worth the effort. I believe that linguistic competence, communicative competence, cultural competence are equally important parts of the foreign language teaching curriculum, study abroad program syllabi as well as the programming goals of foreign cultural centers.

\section{Works Cited}

Ardó, Zsuzsanna. 1994. How to be a European? Go Hungarian! Budapest: Texoft Kft. 2008. Culture Shock! A Survival Guide to Customs and Etiquette. Tarrytown, NY: Marshall Cavendish Corporation.

Chomsky, Noam. 1965. Aspects of the Theory of Syntax. Cambridge: M.I.T. Press.

Cummings, Milton C. 2003. Cultural Diplomacy and the United States Government: A Survey. Washington, D.C: Center for Arts and Culture.

Hymes, Dell H. 1966. "Two types of linguistic relativity." Ed. W. Bright. Sociolinguistics. The Hague: Mouton, 114-158.

— 1972. "On communicative competence." Ed. J.B. Pride and J. Holmes. Sociolinguistics: Selected Readings. Harmondsworth: Penguin, 269-293.

Kramsch, Claire. 2010. "The Cultural Component of Language." Language, Culture and Curriculum 24. London: Routledge.

Krasner, Irene. 1999. "The Role of Culture in Language Teaching." Dialog on 
Sólyom, Erika. "The Role of Cultural Competence in the Teaching of Hungarian as a Foreign Language and in Cultural Diplomacy." Hungarian Cultural Studies. e-Journal of the American Hungarian Educators Association, Volume 7 (2014): http://ahea.pitt.edu DOI: 10.5195/ahea.2014.147

Language Instruction 13/1-2: 79-88. http://www.dliflc.edu

McGuire, Molly. 2010. "Three Simple Words: A Rhetorical Analysis of the Slogan

'Yes We Can'." Advances in Communication Theory and Research 3. http://www.k-state.edu/actr

Mieder, Wolfgang. 2009. 'Yes we can': Barack Obama's Proverbial Rhetoric. New York: Peter Lang Publishing, Inc.

Ogulnick, Karen. 2005. "Learning Language/Learning Self." Intercultural Discourse and Communication. Eds. Scott F. Kiesling and Christina Bratt Paulston. Oxford: Blackwell: 250-254.

Rose, Kenneth and Gabriele Kasper. 2001. Pragmatics in Language Teaching. Cambridge University Press.

Rounds, Carol H. and Erika Sólyom. 2003. Colloquial Hungarian. London: Routledge. $1^{\text {st }}$ edition.

- 2011. Colloquial Hungarian. London: Routledge. $3^{\text {rd }}$ edition.

Sólyom, Erika. 2011. "Linguistic Address Systems in Post-1989 Hungarian Urban Discourse." Comparative Hungarian Cultural Studies. Eds. Steven Tötösy de Zepetnek and Louise O. Vasvári. Purdue University Press: 284-295.

Williams, Todd. 2004. Ti! Magyarok, feketeszemmel. ['You! Hungarians From an African American Perspective']. Budapest: Trottel Books. 